\title{
ASSOCIATION NEWS - 2019
}

National days: All the national days were observed with due importance.

International mother language day (21 February) - observed with fervor;

99th birth anniversary of Bangabandhu (17 March) - observed with honour;

National genocide day (25 March) - observed with grief;

Independence day (26 March) - celebrated with rejoice;

Bangali new year (14 April) - celebrated with festivities;

National mourning Day (15 August) - observed with respect;

Shahid Dr Milon Day (27 November) - observed with gratitude;

Intellectual martyrs day (14 December) - observed with reverence;

Victory Day (16 December) - celebrated with jubilation.

Professional support: In connection with death of a patient in the private National Hospital Khulna, Dr Arafat Azam was inappropriately arrested by RAB. He was given all sorts of legal help from BMA(KB), as decided by the EC meeting on 29 June.

Dr Sujauddin was assaulted and abducted from Khalishpur clinic on 07 September. EC took emergency decision and has been extending legal aid till now. A memorandum was submitted to the law enforcing authorities demanding arrest and punishment of miscreants. Two different protest meeting and strike was observed on $10 \& 12$ September, which eventually resulted in arrest of the hooligans.

On 25 February, Dr Moazzem Hossain and Dr Shahadat Hossain died from a gruesome road traffic accident due to reckless driving of Gorai bus. BMA(KB) had staged demonstration for the cancellation of root permit of the bus and to bring the driver to justice.

Recently, Legal aid fund has been developed by BMA(KB) to support all the judicial activities in future.

Publications: Long cherished 'Doctors Directory' has been published which contains life sketch including professional and permanent address of all the members from different discipline. Doctors in charge of compilation devoted themselves for a long time to make it informative and useful for the concerned persons.

Social function: Social function was observed with respect \& rejoice on different religious days- Iftar Mahfil (28 May); post Durga Puja get-together (16 October) and Christmas day (25 December).

Benevolent activities: Free medical service is rendered to the poor people through Binodini Memorial Hospital since 1962. A free 'Eye camp' was organized with the cooperation of "Bangamata Sheikh Fazilatunnesa Eye Hospital \& Research center" on 08 December. Three hundred fifty eye patients were served in this camp and 60 of them have been selected for cataract operation. Health camp was conducted in the climate conference (two days) of Khulna University and also for the workers of Star jute mill.

Organizational function: Three EC and four emergency meeting were held to take various important decisions. Different subcommittees were made at the first meeting of this EC to expedite the relevant activities. 